\title{
Student's Perception on The Usage of Spanish E-Learning Blog as Online Medium to Strengthen Their Mastery and Comprehension
}

Mariyati Mohd Nor, Harnani Mat Zin, Harozila Ramli

To Link this Article: http://dx.doi.org/10.6007/IJARBSS/v11-i3/8976

DOI:10.6007/IJARBSS/v11-i3/8976

Received: 25 January 2021, Revised: 22 February 2021, Accepted: 03 March 2021

Published Online: 15 March 2021

In-Text Citation: (Nor et al., 2021)

To Cite this Article: Nor, M. M., Zin, H. M., \& Ramli, H. (2021). Student's Perception on The Usage of Spanish ELearning Blog as Online Medium to Strengthen Their Mastery and Comprehension. International Journal of Academic Research in Business and Social Sciences, 11(3), 625-643.

Copyright: (c) 2021 The Author(s)

Published by Human Resource Management Academic Research Society (www.hrmars.com)

This article is published under the Creative Commons Attribution (CC BY 4.0) license. Anyone may reproduce, distribute, translate and create derivative works of this article (for both commercial and non-commercial purposes), subject to full attribution to the original publication and authors. The full terms of this license may be seen

at: http://creativecommons.org/licences/by/4.0/legalcode

Vol. 11, No. 3, 2021, Pg. 625 - 643

Full Terms \& Conditions of access and use can be found at http://hrmars.com/index.php/pages/detail/publication-ethics 


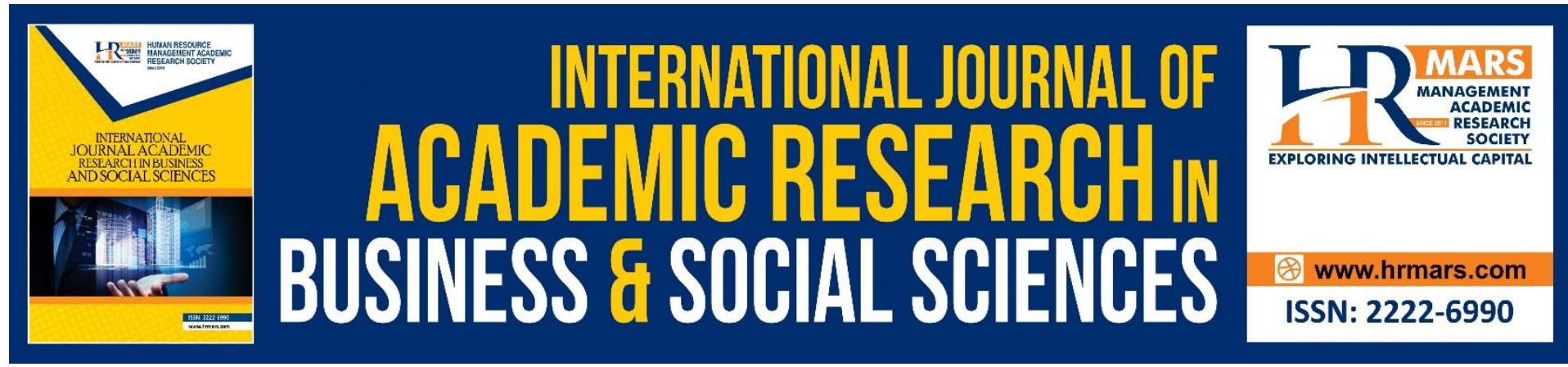

\title{
Student's Perception on The Usage of Spanish E- Learning Blog as Online Medium to Strengthen Their Mastery and Comprehension
}

\author{
Mariyati Mohd Nor, Harnani Mat Zin, Harozila Ramli \\ Universiti Pendidikan Sultan Idris \\ Email: mariyati@pbmpu.upsi.edu.my,harnani@fskik.upsi.edu.my, \\ harozila@fskik.upsi.edu.my
}

\begin{abstract}
E- learning among university students has been one of the effective methods of learning and contributed to more flexsible environment. In Malaysia, other than in-class learning, lecturers also use e-learning as one of the Self Learning Time (SLT) that helps students learn outside of the class. The acceptance of e-learning is not only capable in transforming the traditional teaching and learning, moreover, the usage of technologies in learning gives impacts and more effective and flexsible environment. This study conducted to identify student's perception on Spanish learning blog which developed by lecturer as teaching and learning medium. A questionnaire set was used to collect data for 45 students who took Level one Spanish Language in Sultan Idris Education University (UPSI).The data analysis uses SPSS version 23 software and will be analysed quantitatively and qualitatively. The data was collected using Likert Scale questionnaire and analysed using descriptive statistic, percentage and min. The findings have shown that the student's perception on Spanish teaching and learning bog based on aspects such as user-friendly (4.30), design and interactivity (4.25) and usability and suitability (4.31) were positive with high min score. Findings from interview has portrayed the strengths of the blog were the usage of clear Malay language in describing the content and each of the topic's description has also strengthen student's comprehension. On the other hand, the weaknesses of the organisation and design aspects will be improved based on suggestions and responses acquired in the analysed data. Overall, the usage of this blog in teaching and learning has given positive impact on student's mastery, increasing the comprehension, adding new vocabularies, improving student's achievement also giving more exciting learning experiences to students in learning Spanish language.
\end{abstract}

Keywords: Perception, Blog, E-Learning, Teaching and Learning

\section{Introduction}

21st Century Teaching and Learning Skill is referring to several core competencies, such as colaborative, digital literacy, thinking skills and problem solving. Berry (2011) elaborated that 21st century learning as a learning form which requires student to master the contents and creating, synthesising (unification/mergering) and evaluating information from various subjects and wide sources in understanding and respecting different cultures. Student is 
expected to be able to create, communicate, collaborate and be digital literate. Parallell to the world development in information and communication technologies, teaching and learning process has been changed and deeply impacted due to the current waves of technology. In Universiti Pendidikan Sultan Idris (UPSI), lecturers are compulsary to attend TLAS (Teaching Learning Assessment and Supervision); a series of courses which helps lecturers with various skills related to the technology usage in teaching and learning. Lecturers' participation in these courses is expected to help them in utilising technologies in teaching and learning. Gamification, Flipped Classroom, Blended Learning, Active Learning, Outcome Based Learning, MOOC (Massive Open Online Courses), Challenge Based Learning are among of the current teaching and learning methodologies opted by lecturers as compared to traditional methodology that uses materials such as books and notes. Quizzlet.com, Kahoot.it, Flipgrip, Hot Potatoes are among of the applications used in assessment process, electronically. All courses in university have to emphasise on the 21st Century teaching and learning criteria and lecturers have to be wise in choosing the appropriate and suitable methodology in helping students to learn. Thus, it is not deniable that digital platform is the fastest, interactive, variable, attracts interest and motivates students to learn efficiently. This includes foreign laguage courses in UPSI which requires lecturers to be more creative and innovative.

Blog is one of the platforms in E-learning used in online teaching and learning. Blog, originated from English word, Weblog, is a personal diary, collaborative space, latest news channel and personal memoes link collection for public views. There are various forms and types of blog and there are no specific rules about it. In short, blog is a web site for writer to continuously write about topics or issues that need to be discussed. New issues or topics are published on top for viewers or readers to read the latest posting and comments can be given at the comment column. In education field, blog is used to fulfil various forms of communication needs which help E-learning practices (Susana \& Sergio, 2007). Study by Normaliza (2014) portrayed that blog, clearly helped Korean students in Malay Literature, Malay Language and technology learning. This study involved 60 samples of Korean students who learnt Malay language as foreign language. The findings portrayed students were having fun in learning Malay literature, Malay language and technology using blog. While study by Norzieyana (2004) found that Malay language teaching and learning among the Year 6 school students were more interesting and effective, and suggested that the usage of blog in learning should be be emphasised. Santosa (2017) stated the benefits of blog usage in writing learning had proved students were capable to improve their writings by creating more creative and innovative pieces, dynamic exploration and interaction, better literacy ability more over, the development of workig in group were also applied. Fazlinda (2010) in her study on the blog usage among students of Univeristi Teknologi Malaysia (UTM) proved that students prefer using blog due to factors such as the technology development, social influences and information sharing. The findings of the study also showed students learn using blog because the learning environment were more effective and efficient. Zaki et al, 2015) in study related to application of E-learning in language learning had found that the e-learning application usage had made the language teaching and learning more interactive and very different with the traditional technique and students were happier and more excited. Shahril (2016) in his study related to the usage of Zone of Proximal Development in constructing Spanish sentences found that students prefer using Google Translate to translate and construct sentences in writings as compaed to using books. This is due to the usage of Google Translate gave more accurate grammar (genus, numbers and article and adjective coordination) and lexical 
feedback accordance to the sentence context required by the student. Study by Salina (2016) showed that students use blog as a new methodology in achieving Spanish as foreign language teaching and learning process. Her study viewed students' trend in applying related materials based on student's cognitive level in developing Spanish language blog based on the Piaget's Cognitive Theory approach (1952). Six student blogs were developed by student based on the knowledge learnt in lecture. The study's findings showed student developed blog using three trends which were focus, thoughts and language used. Therefore, the study conducted gave a new dimension in diversify Spanish language learning methodology and gave ideas for future studies to diversify more studies on blog in Spanish language. In Malaysia, the internet users alone has reached 25.08 millions, representing $79 \%$ of Malaysians that made Malaysia, the ninth world nation most active in social sites (Digital Report, 2018)

\section{Learning Blog}

Along with the developent of Technology, Information and Communication in education world, specifically in language learning, this development give challenges to instructors to develop a Iteaching and learning platform which can be utilised by students effectively. There are various free online learning websites can be applied by students to learn including the blog. Spanish as Easy as ABC with Doctora Mariyati Blog ia a blog developed by lecturer with purpose of helping outside classroom learning via online. This learning blog was developed based on the Spanish language teaching structure syllabus in UPSI. Through this blog also, all topics taught in class are descriptively explained and each topic will include language activities and exercises to be practised by students. Students can interact with lecturer in the comment coloumn of each entry and also with their friends. Kennedy (2003) stated that, currently, blog has become a new dimension for lecturer and student to form an interactive and instant publishing device. Student can also access this learning blog using computer, laptop, and smartphone to learn and do the tasks as instructed by lecturer or teacher in the blog. Related writings on Spanish language in this blog can be benifited by all students as an alternative source other than in-class learning. The learning model was developed based on the syllabus taught in class including learning planning, learning execution, evaluation and assessment which help student to learn Spanish language anywhere. Student faces difficulties in understanding Spanish language system such as grammartical gender, verb conjugation, noun matching and adjective in the form of numbers and gender and others (Mariyati, 2019). Therefore, this blog is used as a learning media and source that helps student in mastering Spanish language as foreign language among students in Malaysia. The usage of this blog embolden the reading and writing culture of student compared to the traditional methodology. Lecturer can design atrractive blog site based on their own ideas through videos, pictures and attract student;s interest to read and answer questions asked in the comment coloumn. Other than that, student also can ask questions and discuss in the comment coloumn and the discussion can be also discussed in class. Lecturer also provides opportunity for student to write and realise their imagination through the blog usage. This blog has been fully utilised to the level 1 Spanish language students in UPSI beginning on semester II 2018/2019 session and students can benefitted the teaching and learning in this blog. 
INTERNATIONAL JOURNAL OF ACADEMIC RESEARCH IN BUSINESS AND SOCIAL SCIENCES

Vol. 11, No. 3, 2021, E-ISSN: 2222-6990 @ 2021 HRMARS

Figure 1 : Example of display in the blog

Spanish semudah ABC bersama

Doctora Mariyati

Jom belajar bahasa Sepanyol (Vamos a aprender el español)

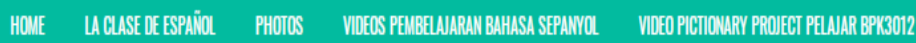

Home » » Kata kerja dalam bahasa Sepanyol (Los Verbos)

Kata kerja dalam bahasa Sepanyol (Los Verbos)

December 04, $2018: 97$ comments :

Buenas Tardes a todos!, Hari ini kita akan belajar mengenai kata kerja dalam bahasa Sepanyol.

Dalam Bahasa Sepanyol, terdapat tiga kumpulan kata kerja,iaitu kata kerja dengan akhiran -ar, -er

dan -ir. Kata-kata kerja ini harus dikonjugasikan mengikut pelaku yang akan melakukan perbuatan

atau pekerjaan yang hendak dilakukan

Konjugasi Pertama (-ar) - hablar(bercakap) estudiar (belajar), trabajar (bekerja), nadar (berenang), montar (menunggang), comprar (membeli), escuchar (mendengar), cantar (menyanyi), bailar (menari) dan sebagainya.

Konjugasi kedua (-er ) - comer (makan), beber (minum), leer (membaca), ver (melihat), comprender (memahami),vender (menjual), aprender (mempelajari), correr (berlari) dan sebagainya

Konjugasi ketiga (- ir) - vivir (tinggal), escribir (menulis), recibir (menerima), abrir (membuka), subir (menaiki), cubrir (menutupi) dan sebagainya.

Konjugasi kata kerja bagi ketiga-tiga akhiran adalah seperti berikut:Image diambil daripada woodwardspanish.com

Search

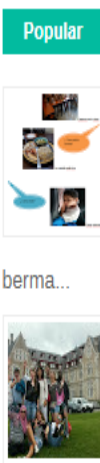

Tags Blog Archives

(no title)

- Kata Kerja ESTAR Kata kerja Ser

dan Estar mempunyai maksud

3. yang sama dalam bahasa Melayu iaitu "ialah dan adalah" dan

Selamat datang ke kelas bahasa

Sepanyol kepada semua.

(Bienvenidos a la clase de

español)

Kepentingan belajar bahasa

Sepanyol Di negara Malaysia, minat menguasai bahasa asing semakin meningkat. Boleh dikatakan semua Uni..

\section{Kata kerja dalam bahasa \\ Sepanyol (Los Verbos) \\ 19. Buenas Tardes a todos!, Hari ini \\ Wal kita akan belajar mengenai kata kerja dalam bahasa Sepanyol.}

Dalam Bahasa Sepanyol, terdapat tiga kumpulan...

Search This Blog 
Figure 2 : Example of teaching and video of verb "TENER"

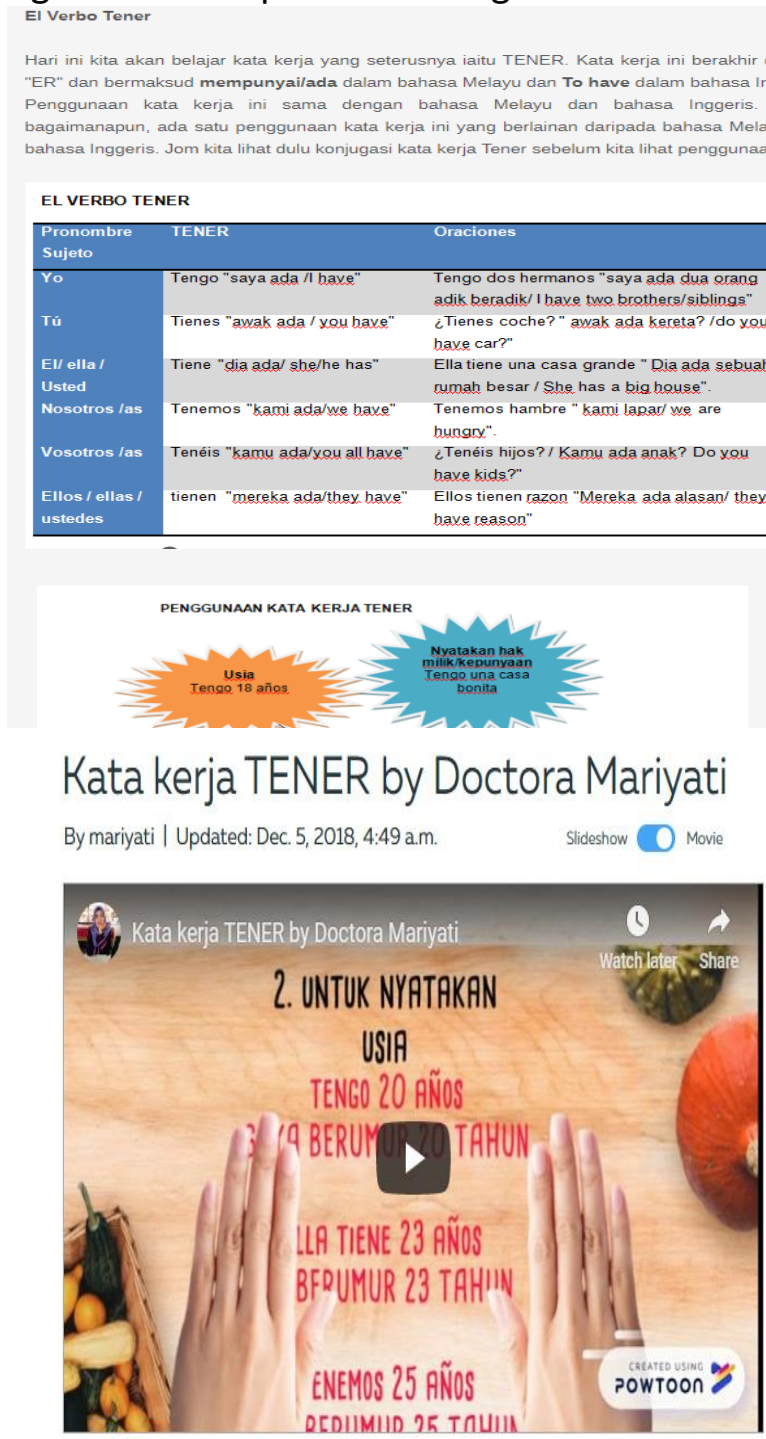

Figure 3 : Activity in the blog

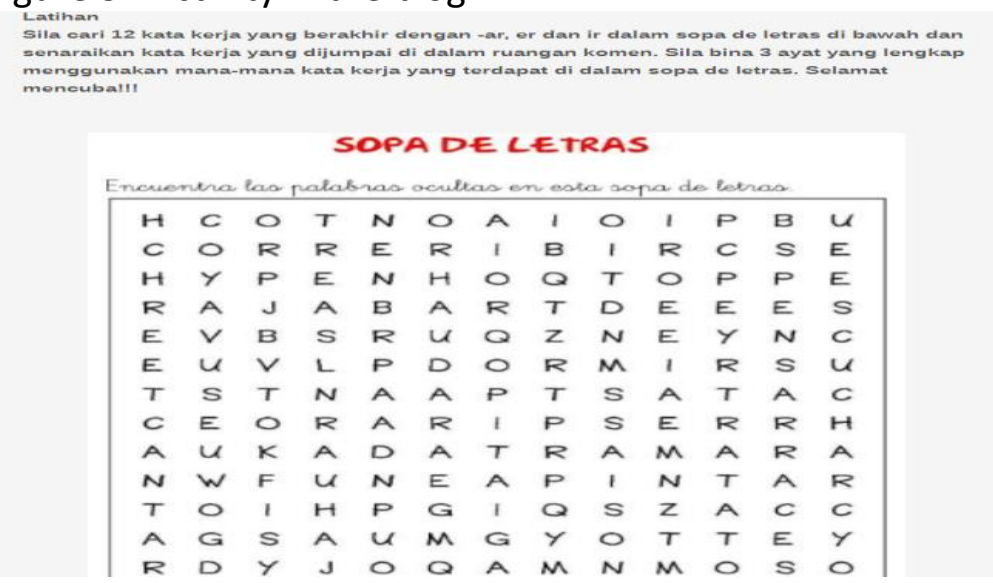

Figure 4 : Student's answers 


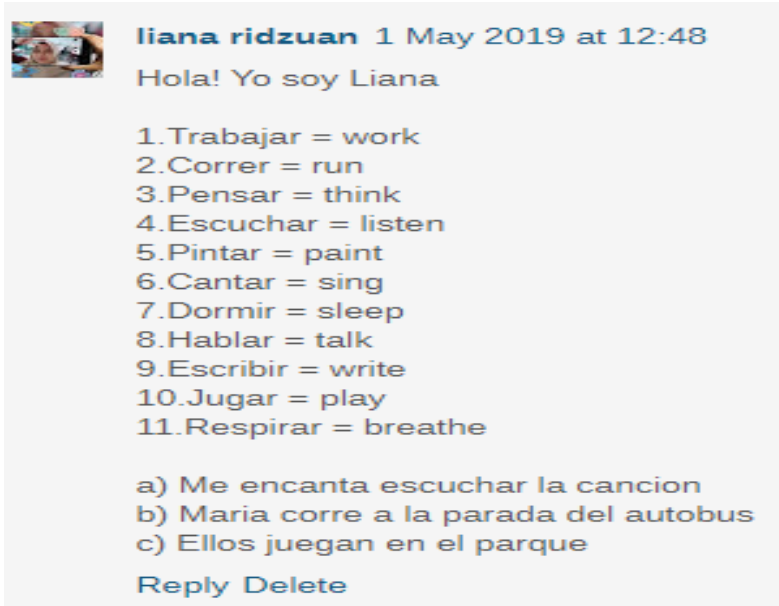

Other than teaching and learning, this blog also provides related information on Spanish culture to increase student's knowledge from culture aspect. This is due to language is inseparable from culture. This finding is parallel to the study conducted by Aydin (2014) who viewed blog writing could increase the culture awareness, interaction, efficiency and knowledge of student in learning a language. One of the example of culture displays in the blog is as followed:

Figure 5: Spanish Traditional Dance: Flamenco.

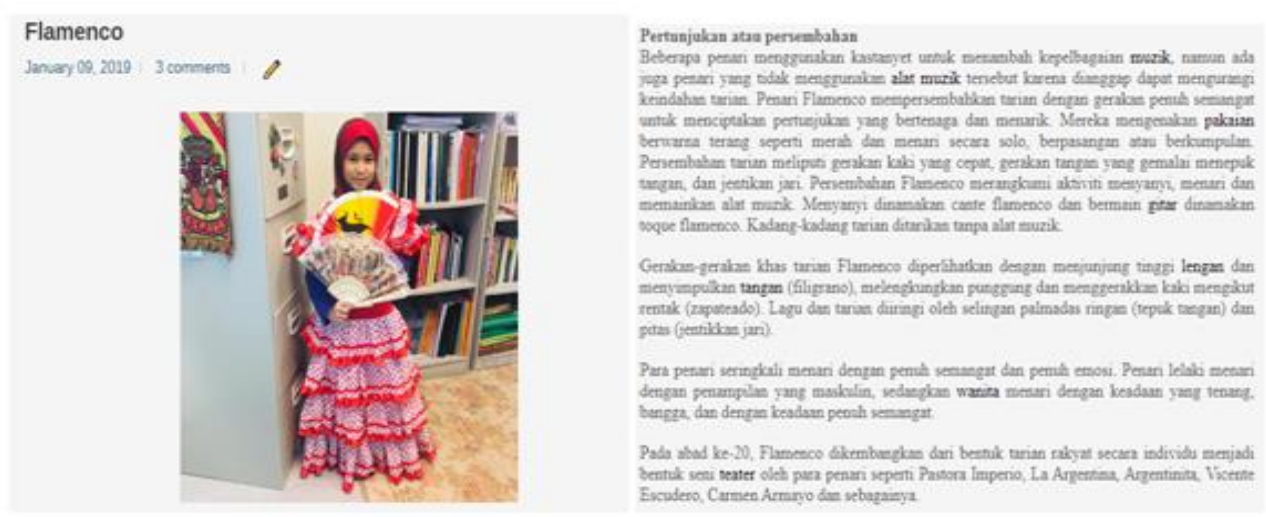

Through this blog also, knowledge sharing will be exchanged among student with other users. Previous student's projects are shared with the current students and the learning process occurred. According to Cabrera (2002) knowledge sharing is an activity which knowledge such as skills, vocabularies, expertise are shared together among the students from other group and other users. Sharing also occurs borderless or without time constraint (Nur, 2009). The usage of blog nowadays, helps a lot in improving the educaton system in Malaysia.

Figure 6: Student's Project Sharing 


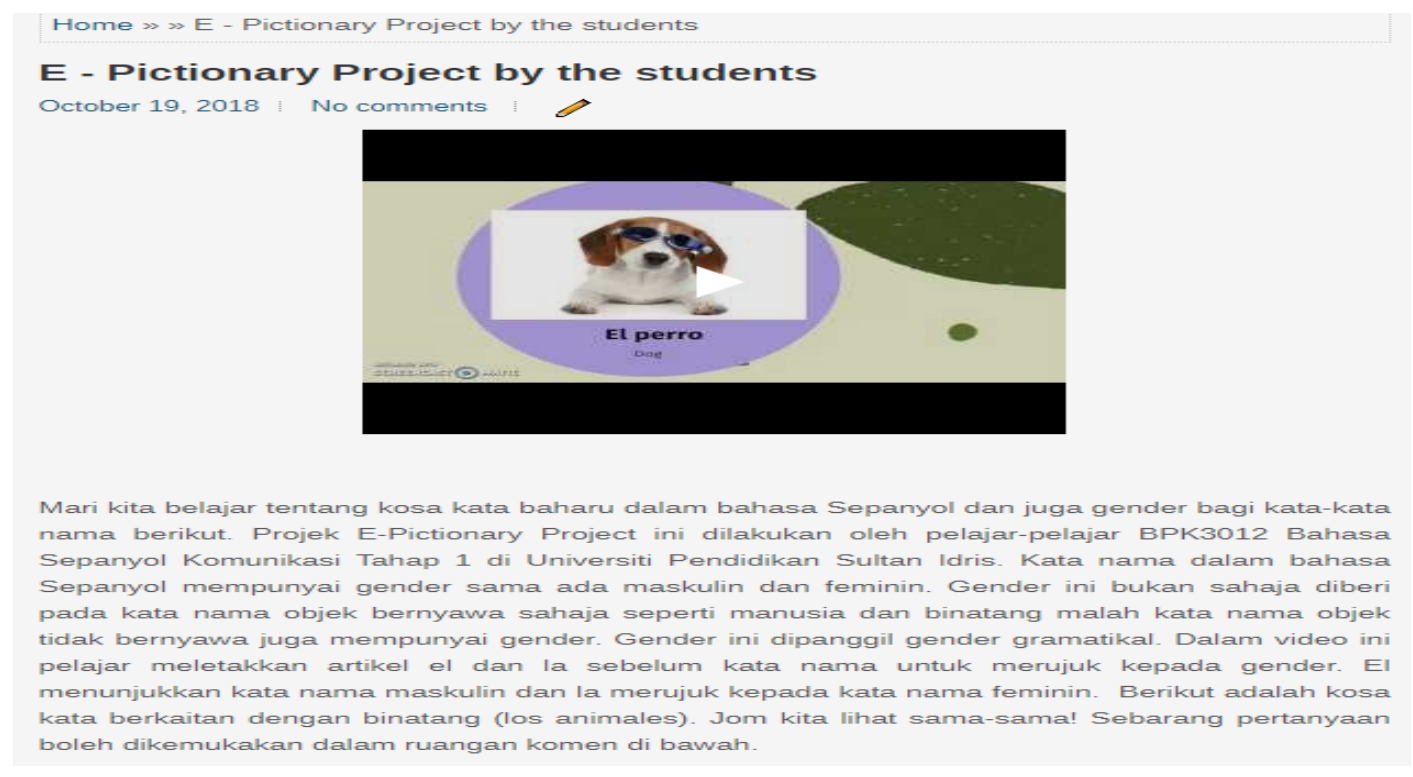

\section{Study Gap}

Most study designs involving the usage of blog to help students learn Spanish language online involve studies conducted in the native speakers of Spanish language. (among of studies; Blanquez Study, 2007; Castro J, 2007; Cortes, 2006; Frey, 2006; Gonzales, 2012; Alonso, 2012) Conducted studies have shown the effectiveness of Spanish language learning among the nonnative students who studied Spanish language as foreign language. The findings showed student learnt with high motivation and showed interest while using blog. Student's technical knowledge also improved and interaction occurred while learning. Blog also provides space for student and lecturer to interact unlimited with each other and through learning interaction, from monologue to dialogue (Efimova and De Moor, 2005; Wrede, 2003). According to Laviña and Mengual (2008), learning community in blog stimulates student's creativity to develop spontaneous learning dimension. Student also explores the pedagogy value in the blog and the collaboration and interaction among the students and lecturer generates good environment and develops new role inside the student as an autonomy agent, idea, content and learning contributor. Similarly with study conducted by Salina (2016) which analysed blog trend developed by Spanish language students during the learning process. This matter is focusing only on learning not teaching which occurred in using blog. Study on the learning blog among Faculty of Education students in Universiti Teknologi Malaysia (UTM) has indicated that students used blog in learning based on the factors of technology development, social influences and information sharing (Noor Fazlinda, 2010). Among of the Spanish language teaching and learning blogs that have been developed by native Spanish speaker are as followed: (Blanquez, 2007) 
Figure 7: Spanish language teaching and learning blog

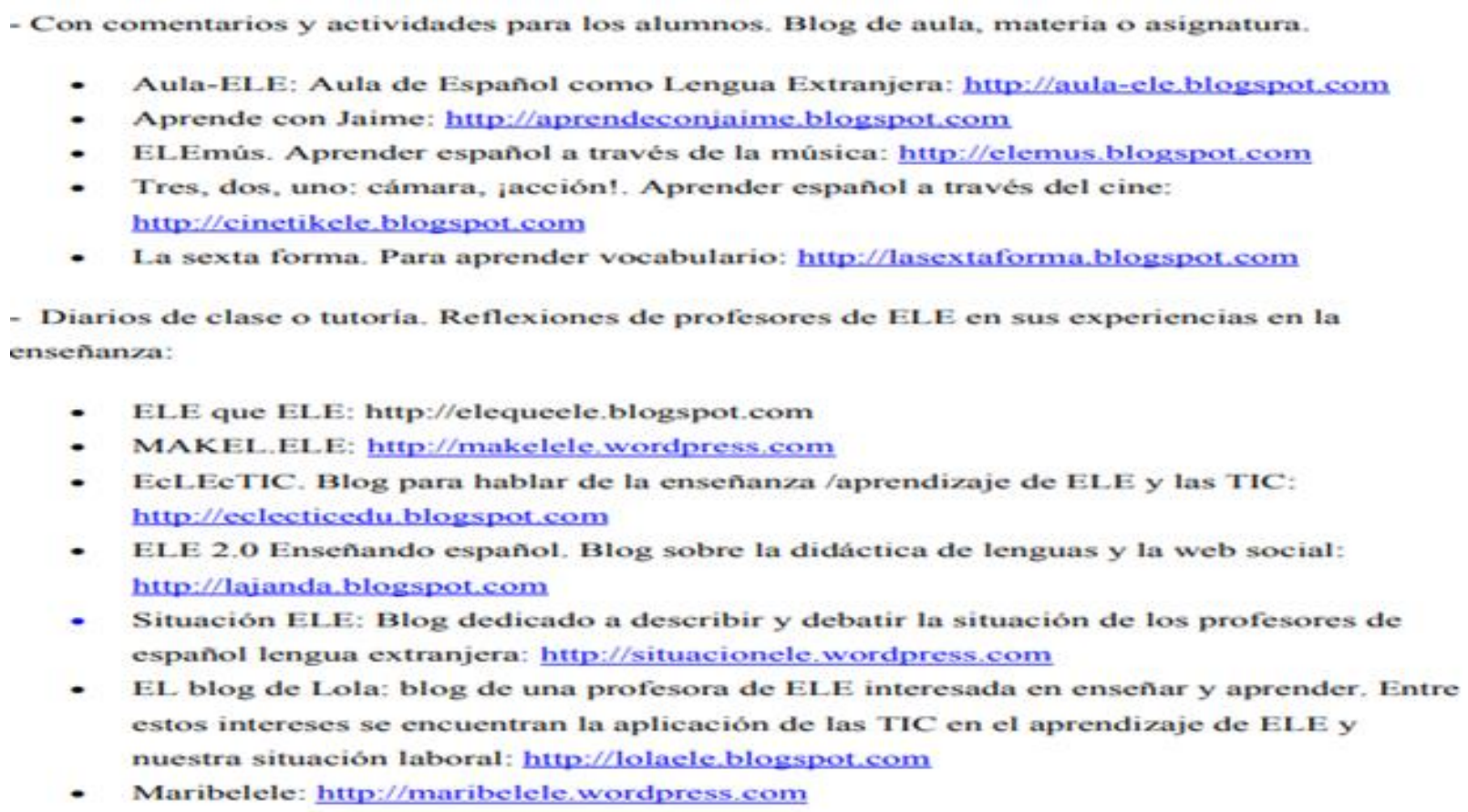

Study by Blanquez (2007) which analising the blog usage in Spanish language class as foreign language had caused the learning process more mitivated and student could adapt with the criteria and skills included in the blog. Other than that, blog also helps teacher in leading and advising, proposing strategies and modes of study and helps student in the process of exploration and learning. This paperwork reflected experiences of using blog as a Spanish language teaching process with a Brazillian student who use Portugese as mother tounge. The purpose of the study was to analyse strategies used while learning Spanish language using blog. On the other hand, the data obtained through the comments kept in the blog, functioning as the analysis to determine language status between lecturer and student. Findings showed that blog usage encouraged autonomous learning and increased motivation in Spanish language learning. Studies conducted by previous researchers involved blogs that were developed by other bloggers in teaching and learning Spanish language in overseas. However, in this study, researcher will analyse student's perception towards the blog developed by non native Spanish language lecturer in the context of teaching and learning Spanish language in Malaysia and the effectiveness of the developed blog. Student's perception towards the blog will be analysed based on three criteria; user friendly, interactivity and design, usage and suitability for student. Apart of that, the strength and weaknesess of the blog can be identified based on the interview questions in the questionnaire. The interview questions can help lecturer in improving the developed blog for its effectiveness on student.

\section{Objective of Study}

This research investigate the student's perception on the usage of Spanish Language Elearning blog as an online medium of enhancing student proficiency and understanding. The research was guided by the following questions.

- What is the student's perception on blog as medium of online learning?

- What are the strength and weaknesses of this blog in helping student learning Spanish language? 
- What are the recommendations for improvement?

\section{Methodology \\ Research Design}

The study conducted used quantitative methodology and supported by qualitative data. The purpose of using both methodologies were to obtain in depth and wide data related to the issue studied (Creswell, 2007). 45 students of Level 1 (Beginner) Spanish Language Communication course were selected. These students took Spanish language course as audit and self-enrichment course. The students were coming from various background, programmes, age, race and gender. Novice students or beginners were chosen as this blog was developed for level 1 novice student and the contents in the blog suited the student's skills level. These students were chosen because all of them had used the Spanish as Ease as ABC with Doctora Mariyati learning blog in semester 1 2019/2020 session.The instrument of the study used questionnaire which had been developed to retrieve information that need to be analysed. The questionnaire consisted of three (3) sections; Section A, Section B and Section $C$. Section A had three (3) questions related to the student's demography; age, race and gender. Section B had three (3) questions on the student's perception in using blog in learning; i)user friendly ii) interactivity and design, iii)usage and suitability. Section $\mathrm{C}$ consisted of three (3) questions related to the strengths, weaknesses and suggestion for improvement of the learning blog. Overall, this questionnaire set had 31 questions in total. Research technique using survey through questionnaire has been widely used as this technique is more effective and practical in obtaining information.

\section{Findings and Discussion}

1) What is student's perception on blog as medium of online learning?

The findings on tstudent perception on this blog will be viewed from the aspect of user friendly, interactivity and design also usage and suitability of this blog on student.

Guide: Low Level = 1 (Min: 1.00-2.33); Medium Level = 2 (Min 2.34-3.66); High Level = 3 (Min: 3.67 - 5.00). 


\section{User Friendly}

Table 1: Percentage and Mean Distribution of User Friendly Level

\begin{tabular}{|c|c|c|c|c|c|c|}
\hline Statement & $\begin{array}{l}1 \\
\text { (Strongly } \\
\text { Disagree) }\end{array}$ & $\begin{array}{l}2 \\
\text { (Disagree) }\end{array}$ & $\begin{array}{l}3 \\
\text { (Not } \\
\text { Sure) }\end{array}$ & $\begin{array}{l}4 \\
\text { (Agree) }\end{array}$ & $\begin{array}{l}\text { 5 } \\
\text { (Strongly } \\
\text { Agree) }\end{array}$ & Mean \\
\hline $\begin{array}{l}\text { 1) MP1 } \\
\text { This blog is easily accessed }\end{array}$ & $\begin{array}{l}1 \\
(2.2 \%)\end{array}$ & 0 & 0 & $\begin{array}{l}17 \\
(37.8 \%)\end{array}$ & $\begin{array}{l}27 \\
(60.0 \%)\end{array}$ & 4.53 \\
\hline $\begin{array}{l}\text { 2) MP2 } \\
\text { Full display in this blog } \\
\text { enables you to view the } \\
\text { content easily }\end{array}$ & $\begin{array}{l}1 \\
(2.2 \%)\end{array}$ & 0 & $\begin{array}{l}2 \\
(4.4 \%)\end{array}$ & $\begin{array}{l}22 \\
(48.9 \%)\end{array}$ & $\begin{array}{l}20 \\
(44.4 \%)\end{array}$ & 4.33 \\
\hline $\begin{array}{l}\text { 3) MP3 } \\
\text { This blog attract your interest } \\
\text { to learn Spanish language }\end{array}$ & $\begin{array}{l}1 \\
(2.2 \%)\end{array}$ & $\begin{array}{l}1 \\
(2.2 \%)\end{array}$ & $\begin{array}{l}3 \\
(6.7 \%)\end{array}$ & $\begin{array}{l}15 \\
(33.3)\end{array}$ & $\begin{array}{l}25 \\
(55.6 \%)\end{array}$ & 4.37 \\
\hline $\begin{array}{l}\text { 4) MP4 } \\
\text { The blog display is attractive } \\
\text { and you are happy to learn } \\
\text { using this blog }\end{array}$ & $\begin{array}{l}1 \\
(2.2 \%)\end{array}$ & $\begin{array}{l}1 \\
(2.2 \%)\end{array}$ & $\begin{array}{l}5 \\
(11.1 \%)\end{array}$ & $\begin{array}{l}18 \\
(40.0 \%)\end{array}$ & $\begin{array}{l}20 \\
(44.4 \%)\end{array}$ & 4.22 \\
\hline $\begin{array}{l}\text { 5) MP5 } \\
\text { You will refer to this blog for } \\
\text { any topics taught in the class } \\
\text { that you do not understand }\end{array}$ & 0 & $\begin{array}{l}4 \\
(8.9 \%)\end{array}$ & $\begin{array}{l}6 \\
(13.3 \%)\end{array}$ & $\begin{array}{l}17 \\
(37.8 \%)\end{array}$ & $\begin{array}{l}18 \\
(40.0)\end{array}$ & 4.08 \\
\hline Overall & & & & & & 4.30 \\
\hline
\end{tabular}

The table above showed five statements which measured student's perception on the blog used for its user friendly feature. Majority of the students agreed that the blog was easy to be accessed online with $27(60 \%)$ strongly agree followed by $17(37.8 \%)$ agree and only one respondent (2.2\%) opted for strongly disagree. MP1 also scored the highest mean, 4.53. MP2 and MP3 scored approximately similar mean which 4.33 and 4.37, indicating that the blog display eased student to view the content and the blog attracted student to learn Spanish language with highest percentage for Strongly Agree and Agree wer 93.3\% for MP2 and $88.9 \%$ for MP3. Students were also agreed that the blog's dsiplay was interactive and they had fun using the blog while learning. MP4 scored the highest, 4.22 with 20 (44\%) strongly agree, followed by $18(40.0 \%)$ agree, 5(11.2\%) not sure and one (2.2\%) disagree and strongly disagree. MP5 indicated the lowest mean score is 4.08 yet still in the highest range. MP5 stated $18(40 \%)$ students strongly agreed that they referred the notes in the blog if the topics taught in class were unclear in class. $17(37.8 \%)$ opted for agree, followed by $6(13.3 \%)$ not sure and $4(8.9 \%)$ disagree. Overall, the mean score stated was high which 4.30 , indicating students were strongly agreed the blog used was user friendly and attract their interest to learn Spanish language. These findings are parallel with the study of the application of Web 2.0 used in Japanese language learning, indicating that web applications that are use friendly supports the teaching and learning process towards 4.0 Industrial Revolution and helps students to learn more efficiently (Muhammad and Sanimah, 2019). 


\section{Interactivity and Design (IR))}

Table 2: Percentage and Mean Distribution of Interactivity and Design

\begin{tabular}{|c|c|c|c|c|c|c|}
\hline Statement & $\begin{array}{l}1 \\
\text { (strongly } \\
\text { disagree) } \\
\end{array}$ & $\begin{array}{l}2 \\
\text { (disagree) }\end{array}$ & $\begin{array}{l}3 \\
\text { (not } \\
\text { sure) }\end{array}$ & $\begin{array}{l}4 \\
\text { (agree) }\end{array}$ & $\begin{array}{l}5 \\
\text { (strongly } \\
\text { agree) }\end{array}$ & Mean \\
\hline $\begin{array}{l}\text { 6) IR1 } \\
\text { This blog is interesting and you } \\
\text { are able to interact with } \\
\text { lecturer in the provided } \\
\text { comment space }\end{array}$ & $\begin{array}{l}1 \\
(2.2 \%)\end{array}$ & 0 & $\begin{array}{l}4 \\
(8.9 \%)\end{array}$ & $\begin{array}{l}18 \\
(40.0 \%)\end{array}$ & $\begin{array}{l}22 \\
(48.9 \%)\end{array}$ & 4.33 \\
\hline $\begin{array}{l}\text { 7) IR2 } \\
\text { Graphic display in the blog are } \\
\text { appropriate and interesting }\end{array}$ & $\begin{array}{l}1 \\
(2.2 \%)\end{array}$ & $\begin{array}{l}1 \\
(2.2 \%)\end{array}$ & $\begin{array}{l}3 \\
(6.7 \%)\end{array}$ & $\begin{array}{l}22 \\
(48.9 \%)\end{array}$ & $\begin{array}{l}18 \\
(40.0 \%)\end{array}$ & 4.22 \\
\hline $\begin{array}{l}\text { 8) IR3 } \\
\text { Font size used are appropriate } \\
\text { abd the content are delivered } \\
\text { well }\end{array}$ & $\begin{array}{l}1 \\
(2.2 \%)\end{array}$ & 0 & $\begin{array}{l}3 \\
(6.7 \%)\end{array}$ & $\begin{array}{l}19 \\
(42.2 \%)\end{array}$ & $\begin{array}{l}22 \\
(48.9 \%)\end{array}$ & 4.33 \\
\hline $\begin{array}{l}\text { 9) IR4 } \\
\text { Style used in explaining each } \\
\text { topic are easily understood } \\
\text { and appropriate }\end{array}$ & $\begin{array}{l}1 \\
(2.2 \%)\end{array}$ & 0 & $\begin{array}{l}1 \\
(2.2 \%)\end{array}$ & $\begin{array}{l}20 \\
(44.4 \%)\end{array}$ & $\begin{array}{l}23 \\
(51.1 \%)\end{array}$ & 4.42 \\
\hline $\begin{array}{l}\text { 10) IR5 } \\
\text { The usage of Malay language } \\
\text { in explaining each topic } \\
\text { strengthened } \\
\text { understanding in learning } \\
\text { Spanish language }\end{array}$ & $\begin{array}{l}2 \\
(4.4 \%)\end{array}$ & 0 & $\begin{array}{l}1 \\
(2.2 \%)\end{array}$ & $\begin{array}{l}16 \\
(35.6 \%)\end{array}$ & $\begin{array}{l}26 \\
(57.8 \%\end{array}$ & 4.42 \\
\hline $\begin{array}{l}\text { 11) IR6 } \\
\text { You will attempt to answer } \\
\text { and practise all available tasks } \\
\text { in the blog }\end{array}$ & $\begin{array}{l}1 \\
(2.2 \%)\end{array}$ & $\begin{array}{l}1 \\
(2.2 \%)\end{array}$ & $\begin{array}{l}6 \\
(13.3 \%)\end{array}$ & $\begin{array}{l}18 \\
(40.0)\end{array}$ & $\begin{array}{l}19 \\
(42.2)\end{array}$ & 4.17 \\
\hline Overall & & & & & & 4.25 \\
\hline
\end{tabular}

Based on the findings in Table 2 above, student's perception level on blog's interactivity and design were high with the average mean score of 4.25 . this can be proven in IR1, students were strongly agreed that this blog was interesting and student were able to interact with lecturerin the provided comment space of each entry posted. Majority of students opted strongly agree, 22 (48.9\%) followed by agree, $18(40.0 \%)$ and not sure $4(8.9 \%)$. There was a student (2.2\%) who opted for strongly disagree. On the design aspect, for graphic display, 40 $(88.9 \%)$ students were strongly agreed and agreed that display was important in gaining student's interest to learn with average mean score of 4.22 . This can be proven through the next item which related to design scored highest mean of 4.33 with $88.9 \%$ agree for IR3 (font) and IR4(style) with mean of 4.42 with $95.5 \%$. These findings indicating that students agreed to style, font and content of topics were explained easily and well. These findings were parallel to the study conducted by Ibrahim, Sing, Sharmeeze, Alias \& Dewitt (2014) which 
reported that matrials with graphics, texts, animations, videos, really help students from the aspect of understanding and remembering foreign language learning easily. One of the benefits Spanish language learning blog is the usage of Malay language and this eases student's understanding in regards of student various social backgrounds. Item IR5 proved that the usage of student's dominant language helped and strengthened student's understanding with high mean score of 4.42. Total of 26 (57.8\%) strongly agree and $16(35.6 \%)$ agree and only $2(4.4 \%)$ strongly disagree. Exercises provided in each entry also gave opportunity to students to test their understanding and received comments from lecturer. Majority of students would try to answer questions and tasks given of total 46 (82.2\%) with mean score of 4.17 while, $6(13.3 \%)$ not sure and the remainance $2(4.4 \%)$ would not try.

Overall mean score for this item showed highest level which 4.25.

3. Usage and Suitability (KK)

Table 3: Percentage and Mean Distribution of Usage and Suitability

\begin{tabular}{|c|c|c|c|c|c|c|}
\hline Statement & $\begin{array}{l}1 \\
\text { (Strongly } \\
\text { disagree) }\end{array}$ & $\begin{array}{l}2 \\
\text { (disagree) }\end{array}$ & $\begin{array}{l}3 \\
\text { (not } \\
\text { sure) }\end{array}$ & $\begin{array}{l}4 \\
\text { (agree) }\end{array}$ & $\begin{array}{l}5 \\
\text { (strongly } \\
\text { agree) }\end{array}$ & Mean \\
\hline $\begin{array}{l}\text { 12).KK1 } \\
\text { This blog helps you learn } \\
\text { Spanish language through } \\
\text { online outside from classroom }\end{array}$ & $\begin{array}{l}1 \\
(2.2 \%)\end{array}$ & 0 & 0 & $\begin{array}{l}15 \\
(33.3 \%)\end{array}$ & $\begin{array}{l}29 \\
(64.4 \%)\end{array}$ & 4.57 \\
\hline $\begin{array}{l}\text { 13). KK2 } \\
\text { This blog increase your } \\
\text { understanding in learning } \\
\text { Spanish language }\end{array}$ & $\begin{array}{l}1 \\
(2.2 \%)\end{array}$ & 0 & 0 & $\begin{array}{l}17 \\
(37.8 \%)\end{array}$ & $\begin{array}{l}27 \\
(60.0 \%)\end{array}$ & 4.53 \\
\hline $\begin{array}{l}\text { 14). KK3 } \\
\text { This blog helps in enhancing } \\
\text { your vocabularies in Spanish } \\
\text { language }\end{array}$ & 0 & $\begin{array}{l}1 \\
(2.2 \%)\end{array}$ & $\begin{array}{l}1 \\
(2.2 \%)\end{array}$ & $\begin{array}{l}20 \\
(44.4 \%)\end{array}$ & $\begin{array}{l}23 \\
(51.1 \%)\end{array}$ & 4.44 \\
\hline $\begin{array}{r}15) \cdot \text { KK4 } \\
\text { You understand better the } \\
\text { Spanish grammar }\end{array}$ & $\begin{array}{l}1 \\
(2.2 \%)\end{array}$ & $\begin{array}{l}1 \\
(2.2 \%)\end{array}$ & $\begin{array}{l}1 \\
(2.2 \%)\end{array}$ & $\begin{array}{l}20 \\
(44.4 \%)\end{array}$ & $\begin{array}{l}22 \\
(48.9 \%)\end{array}$ & 4.35 \\
\hline $\begin{array}{l}\text { 16)KK5 } \\
\text { Lecturer's explaination on the } \\
\text { content of each topic are clear } \\
\text { and easily understood } \\
\text { Notes, } \\
\text { Video, } \\
\text { question/exercise }\end{array}$ & $\begin{array}{l}1 \\
(2.2 \%)\end{array}$ & 0 & $\begin{array}{l}2 \\
(4.4 \%)\end{array}$ & $\begin{array}{l}18 \\
(40.0 \%\end{array}$ & $\begin{array}{l}24 \\
(53.3 \%)\end{array}$ & 4.42 \\
\hline $\begin{array}{l}\text { 17). KK6 } \\
\text { You actively read and do the } \\
\text { tasks in the blog }\end{array}$ & $\begin{array}{l}4 \\
(8.9 \%)\end{array}$ & 0 & $\begin{array}{l}11 \\
(24.4 \%)\end{array}$ & $\begin{array}{l}23 \\
(51.1 \%)\end{array}$ & $\begin{array}{l}7 \\
(15.6 \%)\end{array}$ & 3.73 \\
\hline $\begin{array}{l}\text { 18). KK7 } \\
\text { Content/topic taught in the } \\
\text { blog is suitable with your } \\
\text { Spanish language level }\end{array}$ & $\begin{array}{l}1 \\
(2.2 \%)\end{array}$ & 0 & $\begin{array}{l}2 \\
(4.4 \%)\end{array}$ & $\begin{array}{l}19 \\
(42.2)\end{array}$ & $\begin{array}{l}23 \\
(51.1 \%)\end{array}$ & 4.40 \\
\hline
\end{tabular}




\begin{tabular}{|c|c|c|c|c|c|c|}
\hline $\begin{array}{l}\text { 19).KK8 } \\
\text { You will refer the notes in the } \\
\text { blog before seating for written } \\
\text { or speaking test }\end{array}$ & $\begin{array}{l}1 \\
(2.2 \%)\end{array}$ & $\begin{array}{l}3 \\
(6.7 \%)\end{array}$ & $\begin{array}{l}7 \\
(15.6 \%)\end{array}$ & $\begin{array}{l}22 \\
(48.9 \%)\end{array}$ & $\begin{array}{l}12 \\
(26.7 \%)\end{array}$ & 3.91 \\
\hline 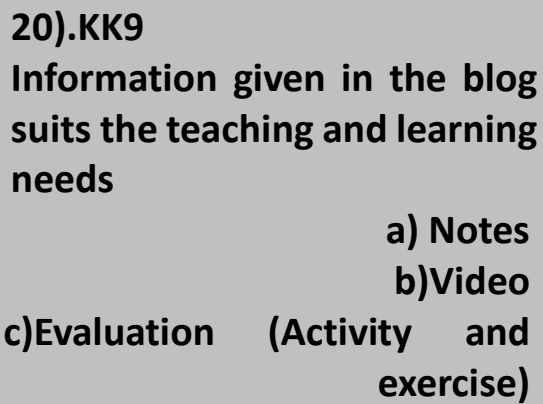 & $\begin{array}{l}1 \\
(2.2 \%)\end{array}$ & 0 & $\begin{array}{l}1 \\
(2.2 \%)\end{array}$ & $\begin{array}{l}21 \\
(46.7 \%)\end{array}$ & $\begin{array}{l}22 \\
(48.9 \%)\end{array}$ & 4.40 \\
\hline $\begin{array}{l}\text { 21).KK10 } \\
\text { Previous student's } \\
\text { video/project sharing also } \\
\text { helps you to create better and } \\
\text { more quality project }\end{array}$ & $\begin{array}{l}1 \\
(2.2 \%)\end{array}$ & $\begin{array}{l}1 \\
(2.2 \%)\end{array}$ & $\begin{array}{l}4 \\
(8.9 \%)\end{array}$ & $\begin{array}{l}17 \\
(37.8 \%)\end{array}$ & $\begin{array}{l}22 \\
(48.9 \%)\end{array}$ & 4.28 \\
\hline $\begin{array}{l}\text { 22).KK11 } \\
\text { E-learning application helps } \\
\text { student in practising SLT (Self } \\
\text { Learning Time). }\end{array}$ & $\begin{array}{l}1 \\
(2.2 \%)\end{array}$ & $\begin{array}{l}1 \\
(2.2 \%)\end{array}$ & 0 & $\begin{array}{l}20 \\
(44.4 \%)\end{array}$ & $\begin{array}{l}23 \\
(51.1 \%)\end{array}$ & 4.42 \\
\hline Overall & & & & & & 4.31 \\
\hline
\end{tabular}

Item related to the usage and suitability referred to the usage of the blog form the aspect of content and its suitability for students. Overall, this study found that on the aspect of the usage and suitability of this blog as student's learning aids, the mean score exceed 4.00 for all items. Item KK1 scored highest mean score of 4.57 which students agreed that this blog helps them learning Spanih language through online outside from classroom. The percentage for strongly agree was also high which 29 (64.4\%), agree 15 (33.3\%) and only one student $(2,2 \%)$ opted strongly disagree. Meanwhile, for item KK2, related to the increase of student's understanding in using blog also scored high mean score 4.53 with the percentage for strongly agree $27(60.0 \%)$ followed by agree $17(37.8 \%)$ and one (2.2\%) for strongly disagree.

Other than the increase of student's understanding, this blog also helped in augmenting new Spanish language vocabularies. Based on the mean score 4.44 for item KK3, a group of students, $23(51.1 \%)$ strongly agree, $20(44.4 \%)$ agree, one (2.2\%) not sure and one $(2.2 \%)$ disagree. Findings from item KK4 also proved that learning through blog helped student to understand Spanish language grammar better. With mean score over 4.00 which 4.35 , the number of students who opted strongly agree and agree was high, 42 students (93.3\%) compared to the number of students who opted for disagree, 2 (4.4\%). Student faced difficulties in understanding Spanish language grammar system which different form their mother tounge and this blog could help as the lecturer's explaination are clear and the language used by lecturer are easy (Mariyati, 2020). This can be proven in item KK5 with mean score of 4.42, students were strongly agreeing that lecturer explaination in discussing the content such as notes, videos, questions and exercises for each topic wee clear and easily 
understood. The percentage for students who strongly agreed and agreed was high, (42 with the percentage of $(93.3 \%), 2(4.4 \%)$ not sure and one (2.2) strongly disagree.

Considering this blog attracted student's interest to learn Spanish language, students were actively reading and doing the exercises and activities of each entry posted. Though scored lowest mean, 3.73 for item KK6, the number of student who agreed were still high which, 23 $(51.1 \%)$ followed by strongly agree $7(15.6 \%)$, not sure $11(24.4 \%)$ and srongly disagree with 4 $(8.9 \%)$

Responses on the content included into the blog were also positive and appropriate. Item KK7 also scored high mean score of 4.40. Students agreed that the content and topics taught in the blog suited the student's skills level and in line with the things taught in classroom. With the highest percentage of 51.1\%, 23 students strongly agreed and $19(42.4 \%)$ agreed while the others were unsure and strongly disagree. KK8 scoredsecond lowest mean score with 3.91 indicating students would refer to the notes or content in the blog other than books and other materials before seating for written and speaking tests. The percentage for strongly agree was a bit low $12(26.7 \%)$ compared to agree 22 (48.9\%), followed by not sure 7(15.6\%), 3 (6.7\%) disagree and one (2.2\%) strongly disagree.

Next item, KK9 related to the information given in the blog including notes, teaching video and evaluation suited the teaching and learning needs, also scored high mean score of 4.40 with the percentage for strongly agree was higher, 22 (48.9\%) compared to agree 21 (46.7\%), not sure and strongly disagree, each with one (2.2\%). Other than learning content and information in the blog, lecturer also helped students by sharing previous student's projects with the current students. This knowledge sharing could increase student's know;edge and understanding related to the tasks. Item KK10 which related to this sharing also scored high mean score 4.28. Student felt that this sharing helped in realizing the future projects and could help in creating more quality product. This item recorded high percentage with 22 (48.9\%) strongly agree, 17 (37.8\%), 4 (8.9\%) not sure and one (2.2\%) disagree and strongly disagree.

Item KK11 is item related to E-learning application in helping students practicing SLT (Student Learning Time) also scored high mean score of 4.42. Students strongly agreed, e-learning helped in slef learning outside from the classroom with high percentage, $95.5 \%$ strongly agree and agree while the others were not sure and strongly disagree. Students were able to control the speed of the learning level according to their ability and the usage of technology in language learning has been accepted by students and gave positive impact on self learning (Yu Li Chen, 2014). Overall, the usage and suitability of this blog on students were very positive with the overall mean score of 4.31 . This matter coincide with the study conducted by Baharudin \& Badusah (2016) which stated that among of the Web 2.0 applications, blog has big potential in supporting and increasing the teaching and learning quality.

\section{Findings on Student Interview Analysis}

Structured interview had been conducted and transcribed for analysis. The findings could be explained as followed. 
2) What is/are the strengths and weaknesses of this blog in helping student to learn Spanish language?

Findings from this interview question related to the strength of Spanish language blog on students could be divided into three aspects; user friendly, interactivity and design also usage and suitability on student. The findings from this interview are as followed:

\section{1.) Strength}

\section{a) User Friendly}

P12: We can easily access and learn Spanish Language outside the classroom and can learn Spanish language at any time

P39: There are translations in Malay language and interesting pictures

P40: This blog attracts my interest to learn and easily access and understood when being read.

\section{b) Interactivity and Design}

P41: This blog has explanation in Malay language which ease student to understand the Spanish language context

P16: Simple information and explanation and easily understood

P45: Detailed explanation and positive feedbacks from lecturer in this blog.

\section{c) Usage and Suitability}

P10: This blog gives opportunity for us to explore the video content which are interesting such as exercises and tasks on verbs and other previous student's tasks

P38: This blog has summarised the topics taught in classroom.

P43: This blog gives me better understanding on Spanish language with the provided exercises.

P27: Notes are given in detailed before the task, Malay language used is easily understood.

These findings are among of the examples of answers given by student in realtion to the strength of the blog used in Spanish language teaching and learning in UPSI. Majority of the students gave positive feedbacks and stated that the blog used is user friendly (20\%), has attractive designs and interactivity which enable interaction to occur (50\%) and very useful also suitable for the student's level (30\%). Meanwhile, findings on the weaknesses aspect, the students' answers are as followed.

\section{2) Weaknesses}

\section{a) User friendly}

P12: The usability of the blog is limited due to the need of internet to enable access.

\section{b) Interactivity and Design}

P12: Lack of Multimedia (picture and audio)

P36: 'interface' weaknesses which troublesome in searching required topics.

P29: The answers for activity questions are exposed in the comment space and can be viewed by other users.

\section{c) Usage and Suitability}

P24: Lack of variation in Spanish language vocabularies.

The weaknesses of the blog in the students' answers were mostly related to the design of the blog which give difficulty in searching title or topic that student would like to learn (60\%). This is due to, the blog is still in the process of improvement and this weakneses is the most noticeable. User friendly (5\%) and the usage and suitability (10\%), Exposed answers in 
comment space (25\%). However, students also had given improvement suggestions for the blog so this blog could be better in helping student to learn Spanish language. Among of the suggestions are:

P33: Changing the blog design to more attractive design and rearrange the notes and exercises to ease the searching of materials by students.

P40: Explanation in English as extra notes for improvement.

P39: Adding appropriate dialogue usage for daily conversation

P17: Adding more exercises and activities

P29: Questions are given in the form of Google Form.

P16: Create quick link or arrange the topic according to the syllabus

These findings showed the students suggestions on the topics to be arranged by creating quick links, the exposed answers in the comment space could be improved by using Google Form so that students could check the answers and not copying their friend's answers also adding more exercises, activities and variations of dialogues so this blog become more attractive and helps students in strengthening their Spanish language.

\section{Conclusion}

In conclusion, student's perception on this blog were positive, students were agreed that this blog helps to strengthen the learning in mastering the Spanish language. These three items which were tested; wether the blog was user friendly, had good interactivity and design also the usage and suitability of the blog on students. The mean score was high with 4.00. Students agreed that this blog helps in outside classroom learning and among of the strengths of this blog was the content taught in Malay language, (the students mother tongue) strengthened the student's understanding. Other than that, activities and exercises in the blog also attracted students to try. The weaknesses such as the blog design which includes the organisation of the content, interface, activities and exercises will be improved continuously in accordance to the suggestions by students. This blog is expected to be able to continuously helping students in mastering Spanish language in UPSI specifically, and in Malaysia generally.

\section{Contribution}

This research will support the three shifts mentioned in the Malaysia Education Blueprint (2013-2025), and Framing Malaysian Higher Education 4.0: Future-Proof Talents especially regarding the aspect of a future-ready curriculum: (a) transformative learning and teaching delivery, and (b) immersive experiential learning. The three shifts mentioned in the Malaysia Education Blueprint are as follows: a) Shift 1: Holistic, Entrepreneurial and Balanced Graduates - the innovative immersive blended learning pedagogical via blog basically assists in decisionmaking based on the principles of innovative pedagogies which tie in with the capabilities of technological learning tools and immersive blended learning cycles. This can improve graduates' quality across intellectual, emotional, and physical dimensions, which in turn, leads to the betterment of society. b) Shift 3: Nation of Lifelong Learners - this research supports this shift by providing support for lifelong learners at all points in their learning journey. c) This can happen through an enabler of Shift 9: Globalised Online Learning, where digital technologies are now considered as part of the popular trend in tertiary education to improve learning effectiveness in lifelong learning environments. In addition, One of the six key attributes in our education is needed by every student to be globally competitive is bilingual proficiency: Every child will be, at minimum, operationally proficient in bahasa Malaysia as the national language and language of unity, and in English as the international language of 
communication. The Ministry will also encourage all students to learn an additional language including Spanish.

\section{Acknowledgement}

This paper is based on the research project entitled "Pembangunan E- Pengajaran dan pembelajaran bahasa Sepanyol bagi meningkatkan penguasaan bahasa asing dalam kalangan pelajar UPSI secara atas talian".The authors would like to extend their gratitude to the Research Management and Innovation Centre (RMIC), Sultan Idris Education University (UPSI) for the University Research Grants (code: 2019-0201-106-01) that helped fund the research.

\section{References}

Alonso, R. (2012). Crosslinguistic influence in second language acquisition. The Encyclopedia Of Applied Linguistics, 1-7.

Aydin, S. (2013). The Use of Blogs in Learning English as a Foreign Language. Mevlana International Journal Education (MIJE). Vol 4 (1), 244-259.

Baharudin, S. H., \& Badusah, J. (2016). Tahap Pengetahuan, Kemahiran dan Sikap Guru SekolahMenengah Terhadap Penggunaan Web 2.0 dalam Pengajaran Bahasa Melayu. Jurnal Pendidikan Bahasa Melayu, 6 (2), 33- 43.

Berry, B. (2011). Teaching 2030: What we must do for our students and our public schools. Now and in the Future. North Carolina: Teachers College Press.

Cabrera, A., and Cabrera, E. F. (2002) Knowledge-Sharing Dilemmas. Organization Studies, 23, 687-710. https://doi.org/10.1177/0170840602235001

Castro, J. (2007). Constraints that enable: Creating spaces for artistic inquiry. Proceedings of the 2007 Complexity Science and Educational Research Conference. 18-20.

Cortes, V. (2006). Teaching lexical bundles in the disciplines: An example from a Writing intensive history class. Linguistics and education 17 (4), 391-406.

Creswell, J. W. (2007). Qualitative inquiry and research design: Choosing among five approaches (2nd ed.). Sage Publications, Inc.

De Moor, A., \& Efimova.L.(2005) An Argumentation Analysis of Weblog Conversations. Conference: Proc. of the 9th International Working Conference on the Language-Action Perspective on Communication Modelling (LAP 2004), Rutgers University, New Jersey.

Husain, S., Ismail, Z. M., \& Danuri, N. (2016). Trend Pembinaan Blog dalam Pembelajaran Bahasa Sepanyol. Jurnal Kemanusiaan, 10 (1)59-69.

Ismail, S., \& Sim, T. S. (2016). Aktiviti Pengaturan Menggunakan Zone of Proximal Development dalam Menstruktur Ayat Bahasa Sepanyol. GEMA Online ${ }^{\circledast}$ Journal of Language Studies Volume 16(3), 167-185. http://doi.org/10.17576/gema-2016-160311.

Mora, S. L., Espinosa, S. J. (2007). The Use of Weblogs in Higher Education: Benefits and Barriers. Proceedings of the International Technology, Education and Development Conference (INTED 2007), p. 1-7: IATED, Valencia (Spain), March 7-9 2007.

Nor, M. M.,\& Mansor, N. S. (2020). Disorder of Spanish Verbs Usage in the Production of Grammatical Sentences Based on Pictures. International Journal of Academic Research in Business and Social Sciences, 10 (7), 86-102. http://dx.doi.org/10.6007/IJARBSS/v10i7/7398.

Nor, M.M., Tan,L.N., Salleh,M, N., 2019).Kepekaan dan Kefahaman pelajar terhadap aplikasi gender gramatikal dalam pembinaan ayat bahasa Sepanyol. Jurnal Perspektif. Vol. 11 Bil. 2(1525). 
Othman, N. F. (2010). Kajian Penggunaan Blog Dalam Kalangan Pelajar Fakulti Pendidikan Universiti Teknologi Malaysia. (Disertasi Sarjana, Universiti Teknologi Malaysia. Retrieved from http://eprints.utm.my/id/eprint/28496.

Redzuan, M. A., \& Husin, S. (2019). Sikap dan Persepsi Pelajar Terhadap Penggunaan Aplikasi Web 2.0 dalam Proses Pengajaran dan Pembelajaran Bahasa Jepun di Universiti Putra Malaysia. Jurnal Linguistik Vol. 23 (1) 051-057.

Rahim, A. N. (2014). Learning through Blog Writing Embracing the Technology. Kuala Terengganu : Penerbit UMT.

Santosa, M. H. (2017). Learning approaches of Indonesian EFL Gen Z Students is a Flipped Learning context. Journal on English as a foreign language, 7(2). 183-208.

Wrede, O. (2003). Weblogs and Discourse - Weblogs as a transformational technology for higher education and academic research. Conference: BlogTalk 2003. Vienna.

Chen, Y. L.(2014). A Study on Student Selfefficacy and Technology Acceptance Model within an Online Taskbased Learning Environment. Journal of Computers, 2014, 9 (1): 34-43.

Zaki, A.,Ghani, A. K., Hassan, A. T., Rahman, A. A., Rahman, N. A., Hai, A. A. A., \& Baharuddin,

Q. F. (2015). Aplikasi E-Pembelajaran untuk proses pembelajaran dan pengajaran bahasa : Fungsi dan Kelebihan. Seminar Antarabangsa Pendidikan dan Keusahawanan Sosial Islam.12-14 Oktober 2015. 